\title{
Determination of Elemental and Ionic Compositions for Diesel Exhaust Particles by Particle Induced X-ray Emission and Ion Chromatography Analysis
}

\author{
Katsumi Saitoh, ${ }^{* 1 \dagger}$ Koichiro Sera, ${ }^{* 2}$ Tadashi ShiraI, ${ }^{* 3}$ Tatsuji Sato, ${ }^{* 4}$ and Matsuo Odaka*4 \\ *1 Environmental Research \& Information Center of Akita Prefecture, 3-1-1 Sanno, Akita 010-8572, Japan \\ *2 Cyclotron Research Center, Iwate Medical University, 348 Tomegamori, Takizawa 020-0173, Japan \\ *3 Tokyo Dylec Co., Ltd., 29 Daikyo-cyo, Shinjuku, Tokyo 160-0015, Japan \\ *4 National Traffic Safety and Environment Laboratory, 7-42-27 Jinndaiji-Higashi, \\ Chofu, Tokyo 182-0012, Japan
}

\begin{abstract}
The purpose of this study is to clarify the chemical characterization of $\mathrm{PM}_{2.5}$ and $\mathrm{PM}_{10}$ in diesel exhaust particles (DEP). Sampling of $\mathrm{PM}_{2.5}$ and $\mathrm{PM}_{10}$ in DEP was carried out in November 1999 using an automobile exhaust testing system at the National Traffic Safety and Environment Laboratory, with a diesel truck (engine type: direct injection, displacement: $7961 \mathrm{cc}$, carrying weight: $2020 \mathrm{~kg}$, equivalent inertia weight: $5600 \mathrm{~kg}$ ) placed on a chassis dynamometer. Sampling conditions included idling, constant speed of $40 \mathrm{~km} / \mathrm{h}, \mathrm{M}-15$ test pattern and 60\%-revolution/40\%-load of maximum power. Samples were collected on a polycarbonate membrane filter (Nuclepore ${ }^{\circledR}$, pore size: $0.8 \mu \mathrm{m}$ ) using a MiniVol Portable Air Sampler (Airmetrics Co., Inc.). The concentrations of several elemental and ionic species in the $\mathrm{PM}_{2.5}$ and $\mathrm{PM}_{10}$ samples were determined by particle induced X-ray emission (PIXE) and ion chromatography analysis. PIXE analysis of the $\mathrm{PM}_{2.5}$ and $\mathrm{PM}_{10}$ samples revealed 15 elements, of which $\mathrm{Na}, \mathrm{Mg}, \mathrm{Si}, \mathrm{S}, \mathrm{Cl}, \mathrm{Ca}, \mathrm{Fe}$ and $\mathrm{Zn}$ were found to be the major components. Ionic species were $\mathrm{Cl}^{-}, \mathrm{NO}_{2}^{-}, \mathrm{NO}_{3}^{-}, \mathrm{SO}_{4}{ }^{2-}, \mathrm{Na}^{+}, \mathrm{NH}_{4}^{+}, \mathrm{K}^{+}$and $\mathrm{Ca}^{2+}$. Concentrations of elements and ionic species under the sampling condition of $60 \%$-revolution/40\%-load were highest in comparison with those of the other sampling conditions. The elemental and ionic species data were compared for $\mathrm{PM}_{2.5}$ and $\mathrm{PM}_{10} ; \mathrm{PM}_{2.5}$ concentrations were $70 \%$ or more of $\mathrm{PM}_{10}$ concentrations for the majority of elements, and concentrations of ionic species in $\mathrm{PM}_{2.5}$ and $\mathrm{PM}_{10}$ were almost identical.
\end{abstract}

(Received October 9, 2002; Accepted January 24, 2003)

\section{Introduction}

In megalopolis Japanese cities, severe air pollution due to suspended particulate matter (SPM: particles with diameter less than $10 \mu \mathrm{m}$ ) occurs frequently, and the achievement rate of ambient air quality standards of Japan for SPM is low for long periods. ${ }^{1}$ Many reports have suggested that one of the reasons for this SPM pollution is the large quantity of diesel exhaust particles (DEP). ${ }^{2-4}$ As DEP are fine grained, they are inhaled deep within the respiratory system and easily adhere to it, and concerns have been pointed out that it may affect respiratory disorders. ${ }^{5-7}$ Methods for evaluating the proportion that DEP contributes to atmospheric $\mathrm{PM}_{2.5}$ and $\mathrm{PM}_{10}$ use as an indicator soot, i.e., elemental carbon (EC), which is generally at the core of DEP, ${ }^{4,8}$ but according to a report ${ }^{9}$ by the Japan Clean Air Program (JCAP), the proportion of EC in DEP ranges from $50 \%$ to $85 \%$, although it differs depending on the engine standard, combustion type and the presence or absence of a catalytic converter. Since there is variation in the proportion of EC in DEP, the proportion that DEP contributes to atmospheric $\mathrm{PM}_{2.5}$ and $\mathrm{PM}_{10}$ as an indicator of $\mathrm{EC}$ may be overestimated or underestimated. According to the report ${ }^{9}$ by the JCAP, soluble

\footnotetext{
† To whom correspondence should be addressed.

E-mail: XLL04042@nifty.ne.jp
}

organic fraction $(\mathrm{SOF})$, another main component of DEP, is 15 $48 \%$. On the other hand, the proportion that DEP contributes to atmospheric $\mathrm{PM}_{2.5}$ and $\mathrm{PM}_{10}$ can also be evaluated using the chemical mass balance $(\mathrm{CMB})$ method, ${ }^{10}$ but it requires a detailed elemental and ionic composition profile of $\mathrm{PM}_{2.5}$ and $\mathrm{PM}_{10}$ in DEP. However, as far as we know there is no such detailed elemental and ionic composition profile of these.

Consequently, we have begun to study a multi-probe chemical characterization and composition profile for $\mathrm{PM}_{2.5}$ and $\mathrm{PM}_{10}$ in DEP. Sampling of $\mathrm{PM}_{10}$ and $\mathrm{PM}_{2.5}$ in DEP was carried out using an automobile exhaust testing system, with a diesel truck placed on a chassis dynamometer, and samples of the $\mathrm{PM}_{2.5}$ and $\mathrm{PM}_{10}$ were collected on a polycarbonate membrane filter. Elemental compositions in the filter samples of $\mathrm{PM}_{2.5}$ and $\mathrm{PM}_{10}$ were determined by means of particle induced X-ray emission (PIXE) analysis, which allows analysis of minute samples smaller than a milligram without any complex chemical manipulation. It not only simultaneously detects elements from $\mathrm{Na}$ to $\mathrm{U}$ in a short time but also detects major-to-ultratrace elements at the concentration levels of ppm to sub-ppb. Ionic species (anion: $\mathrm{F}^{-}, \mathrm{Cl}^{-}, \mathrm{NO}_{2}^{-}, \mathrm{Br}^{-}, \mathrm{NO}_{3}^{-}, \mathrm{PO}_{4}{ }^{3-}, \mathrm{SO}_{4}{ }^{2-}$ and $\mathrm{C}_{2} \mathrm{O}_{4}{ }^{2-}$; cation: $\mathrm{Na}^{+}, \mathrm{NH}_{4}^{+}, \mathrm{K}^{+}, \mathrm{Mg}^{2+}$ and $\mathrm{Ca}^{2+}$ ) in the filter samples were analyzed by ion chromatography.

The present paper focuses on characterizing the elemental compositions and ionic species of DEP and on examining the changes in element and ionic species concentrations in DEP 


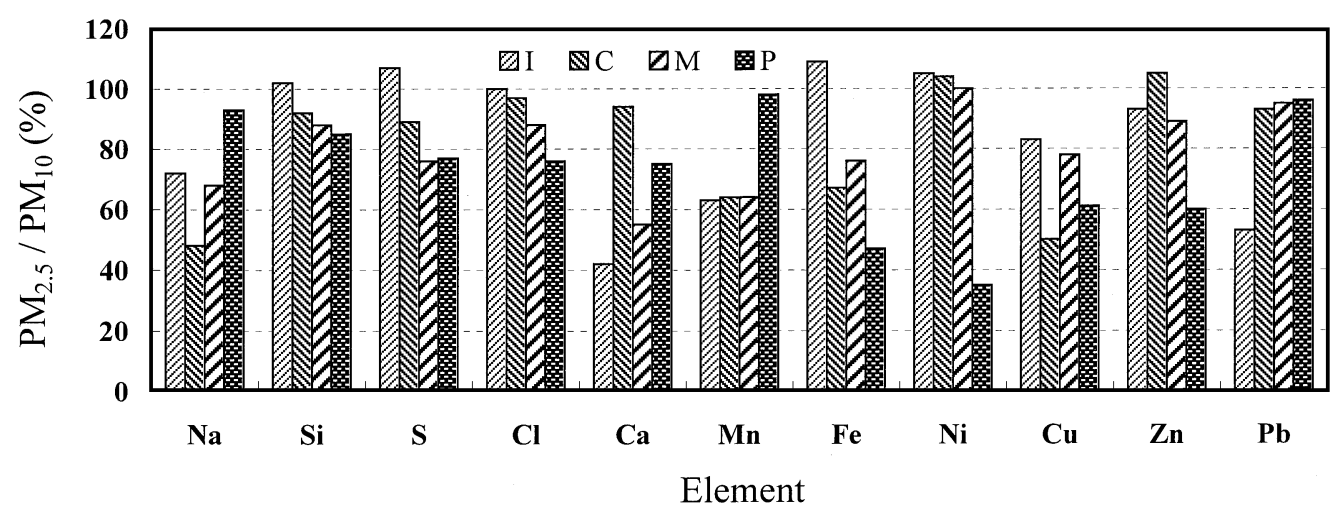

Fig. 1 Elemental concentration rate of $\mathrm{PM}_{2.5}$ and $\mathrm{PM}_{10}$. I: idling, C: constant speed of $40 \mathrm{~km} / \mathrm{h}, \mathrm{M}$ : M-15 test pattern, P: $60 \%$-revolution $/ 40 \%$-load.

Table 1 Specification of the tested truck

$\begin{array}{ll}\text { Vehicle } & 5 \mathrm{M} / \mathrm{T} \\ \text { Transmission } & 2 \\ \text { Passengers } & 2020 \mathrm{~kg} \\ \text { Carrying weight } & 3430 \mathrm{~kg} \\ \text { Vehicle weight } & 7815 \mathrm{~kg} \\ \text { Gross vehicle weight } & 5600 \mathrm{~kg} \\ \text { Equivalent inertia weight } & \\ \text { Engine } & 7961 \mathrm{cc} \\ \text { Displacement } & 200.0 \mathrm{hp} / 2900 \mathrm{rpm} \\ \text { Maximum power } & 54.0 \mathrm{kgm} / 1700 \mathrm{rpm} \\ \text { Maximum torque } & \text { Direct injection } \\ \text { Type } & \end{array}$

resulting from changes in the traveling conditions of a diesel truck. It also addresses acquiring basic data for a chemical composition profile related to DEP for use with the CMB method.

\section{Experimental}

Sampling of $\mathrm{PM}_{2.5}$ and $\mathrm{PM}_{10}$ in DEP was carried out in November 1999 using an automobile exhaust testing system at the National Traffic Safety and Environment Laboratory, with a diesel truck placed on a chassis dynamometer. Specifications of the tested truck are listed in Table 1. Sampling conditions included idling, constant speed of $40 \mathrm{~km} / \mathrm{h}, \mathrm{M}-15$ test pattern and $60 \%$-revolution $/ 40 \%$-load of maximum power. Samples were collected on a polycarbonate membrane filter (Nuclepore ${ }^{\circledR}$, pore size: $0.8 \mu \mathrm{m}$ ) using a MiniVol Portable Air Sampler (Airmetrics Co., Inc.). Flow-rate was 5 1/min. $\mathrm{PM}_{2.5}$ and $\mathrm{PM}_{10}$ samples were obtained with the MiniVol Portable Air Sampler by sampling exhaust diluted $8-18$ fold (idling: 18-fold, constant speed of $40 \mathrm{~km} / \mathrm{h}$ : 8 -fold, M-15 test pattern: 10 -fold, $60 \%$-revolution/40\%-load of maximum power: 8 -fold) using dilution air after introducing exhaust emitted from the engine exhaust pipe into a dilution tunnel attached to the automobile exhaust testing system.

The filter samples were sealed in plastic bags and kept in portable refrigerators during transport back to the laboratory, and they were stored in a freezer $\left(-35^{\circ} \mathrm{C}\right)$ until they were analyzed. Elemental concentrations in the samples were determined by PIXE at Nishina Memorial Cyclotron Center, Japan Radioisotope Association. For PIXE analysis, samples were mounted on a target frame made of Mylar film, and bombarded with $2.9 \mathrm{MeV}$ protons from a baby cyclotron. ${ }^{11}$ Beam currents, the accumulated charge and the typical measuring time were $33-60 \mathrm{nA}, 30-40 \mu \mathrm{C}$ and $15-20 \mathrm{~min}$, respectively. X-ray spectra were analyzed using the SAPIXE program. ${ }^{11}$ Quantitative analysis of elements was based on the Nuclepore-Br method. ${ }^{12}$ Moreover, blank filters were analyzed with all the techniques, and the concentrations of elements that could be measured in the blank filters were always below the minimum detection limits. Ionic species in the samples were determined by ion chromatography (Dionex, DX-120). For ion chromatography analysis, half of a filter was directly treated with $10 \mathrm{ml}$ of ultra-pure water (made by Milli-Q Labo) for 10 min using an ultrasonic apparatus. As for operating conditions during ion chromatography, the sample injection volume was 50 $\mu \mathrm{l}$ and the conductivity detection response was $10 \mu \mathrm{S}$. Blank filters were analyzed with all the techniques, and the concentrations of ionic species that could be measured for the blank filters were always below the minimum determination limits. Ionic species concentrations were determined based on calibration curves generated from analysis of the continuing calibration standard solutions. Wako Pure Chemical Industries, Ltd.'s $1000 \mathrm{mg} / \mathrm{l}$ standard was used for the standard solution. The concentration of calibration standard solutions is zero (ultra-pure water), 0.005, 0.01, 0.05, 0.1, 0.5, 1, 2 and $2.5 \mathrm{mg} / \mathrm{l}$. For generation of calibration curves, determination of each concentration was repeated five times.

\section{Results and Discussion}

\section{Elemental composition}

In PIXE analysis of the $\mathrm{PM}_{2.5}$ and $\mathrm{PM}_{10}$ samples, 15 elements ( $\mathrm{Na}, \mathrm{Mg}, \mathrm{Si}, \mathrm{S}, \mathrm{Cl}, \mathrm{Ca}, \mathrm{Ti}, \mathrm{V}, \mathrm{Cr}, \mathrm{Mn}, \mathrm{Fe}, \mathrm{Ni}, \mathrm{Cu}, \mathrm{Zn}$ and $\mathrm{Pb}$ ) were determined in total. Errors for the analytical results are mainly from the spectrum fitting, the detection efficiency and the values of $\mathrm{X}$-ray transmission through the absorber. Estimated relative error $(100 \times$ error/count, in \%) was smaller than $10 \%$ for four elements $(\mathrm{Ca}, \mathrm{Cr}, \mathrm{Fe}$ and $\mathrm{Zn}), 10-20 \%$ for two elements ( $\mathrm{Si}$ and $\mathrm{S}$ ) and $20-40 \%$ for seven elements $(\mathrm{Mg}$, $\mathrm{Ti}, \mathrm{V}, \mathrm{Mn}, \mathrm{Ni}, \mathrm{Cu}$ and $\mathrm{Pb}$ ). The accuracy of the PIXE analysis was confirmed by an analysis that used NIST standards. ${ }^{13}$

Table 2 shows the elemental concentrations of $\mathrm{PM}_{2.5}$ and $\mathrm{PM}_{10}$ in DEP under the sampling conditions. The elemental concentrations shown in Table 2 are the actual values from the truck exhaust calculated based on the dilution ratio, i.e., the emission volumes. Elements detected under all sampling 
Table 2 Elemental concentrations $\left(\mu \mathrm{g} / \mathrm{m}^{3}\right)$ of the $\mathrm{PM}_{2.5}$ and $\mathrm{PM}_{10}$ in DEP under the sampling conditions

\begin{tabular}{|c|c|c|c|c|c|c|c|c|}
\hline \multirow{2}{*}{ Element } & \multicolumn{4}{|c|}{$\mathrm{PM}_{2.5}$} & \multicolumn{4}{|c|}{$\mathrm{PM}_{10}$} \\
\hline & Idling & $40 \mathrm{~km} / \mathrm{h}$ & M-15 & $60 \% / 40 \%$ & Idling & $40 \mathrm{~km} / \mathrm{h}$ & M-15 & $60 \% / 40 \%$ \\
\hline $\mathrm{Na}$ & 44.1 & 44.6 & 65.3 & 290 & 61.6 & 92.8 & 95.9 & 312 \\
\hline $\mathrm{Mg}$ & $\mathrm{ND}^{\mathrm{a}}$ & ND & ND & 139 & 47.7 & 51.8 & 48.4 & 246 \\
\hline $\mathrm{Si}$ & 23.8 & 37.6 & 28.4 & 538 & 23.4 & 40.4 & 32.5 & 634 \\
\hline S & 130 & 81.6 & 63.0 & 274 & 122 & 92.0 & 82.5 & 355 \\
\hline $\mathrm{Cl}$ & 13.0 & 16.2 & 22.2 & 90.4 & 13.0 & 16.7 & 25.1 & 118 \\
\hline $\mathrm{Ca}$ & 2.0 & 4.2 & 7.3 & 54.6 & 4.9 & 4.5 & 13.2 & 72.9 \\
\hline $\mathrm{Ti}$ & ND & ND & ND & 1.9 & 1.4 & 4.6 & 1.3 & 8.2 \\
\hline $\mathrm{V}$ & ND & 0.2 & ND & 0.5 & ND & 1.4 & ND & 2.5 \\
\hline $\mathrm{Cr}$ & 0.4 & ND & ND & 5.3 & 0.4 & ND & ND & 0.7 \\
\hline $\mathrm{Mn}$ & 0.4 & 0.6 & 0.8 & 4.2 & 0.6 & 1.0 & 1.0 & 4.3 \\
\hline $\mathrm{Fe}$ & 0.6 & 0.5 & 1.1 & 45.4 & 0.6 & 0.8 & 1.4 & 95.2 \\
\hline $\mathrm{Ni}$ & 0.1 & 0.1 & 0.2 & 0.8 & 0.1 & 0.1 & 0.2 & 2.2 \\
\hline $\mathrm{Cu}$ & 0.3 & 0.3 & 0.6 & 2.5 & 0.3 & 0.5 & 0.8 & 4.0 \\
\hline $\mathrm{Zn}$ & 1.5 & 2.6 & 3.4 & 16.6 & 1.7 & 2.5 & 3.8 & 27.5 \\
\hline $\mathrm{Pb}$ & 0.3 & 0.5 & 0.8 & 3.2 & 1.1 & 0.5 & 0.8 & 3.3 \\
\hline
\end{tabular}

a. Not detectable. $40 \mathrm{~km} / \mathrm{h}$ : constant speed of $40 \mathrm{~km} / \mathrm{h}, \mathrm{M}-15$ : M-15 test pattern, 60\%/40\%: 60\%-revolution/40\%-load.

Table 3 Ionic species concentrations $\left(\mu \mathrm{g} / \mathrm{m}^{3}\right)$ of the $\mathrm{PM}_{2.5}$ and $\mathrm{PM}_{10}$ in DEP under the sampling conditions

\begin{tabular}{|c|c|c|c|c|c|c|c|c|}
\hline \multirow{2}{*}{ Element } & \multicolumn{4}{|c|}{$\mathrm{PM}_{2.5}$} & \multicolumn{4}{|c|}{$\mathrm{PM}_{10}$} \\
\hline & Idling & $40 \mathrm{~km} / \mathrm{h}$ & M-15 & $60 \% / 40 \%$ & Idling & $40 \mathrm{~km} / \mathrm{h}$ & M-15 & $60 \% / 40 \%$ \\
\hline $\mathrm{F}^{-}$ & $\mathrm{ND}^{\mathrm{a}}$ & ND & ND & ND & ND & ND & ND & ND \\
\hline $\mathrm{Cl}^{-}$ & ND & ND & ND & 174 & ND & ND & ND & 174 \\
\hline $\mathrm{NO}_{2}^{-}$ & 23.9 & 42.6 & 118 & 291 & 56.0 & 64.0 & 222 & 291 \\
\hline $\mathrm{Br}^{-}$ & ND & ND & ND & ND & ND & ND & ND & ND \\
\hline $\mathrm{NO}_{3}^{-}$ & 23.9 & 21.4 & 74.1 & 233 & 23.9 & 21.4 & 163 & 153 \\
\hline $\mathrm{PO}_{4}^{3-}$ & ND & ND & ND & ND & ND & ND & ND & ND \\
\hline $\mathrm{SO}_{4}^{2-}$ & 200 & 85.6 & 74.1 & 523 & 134 & 85.6 & 88.9 & 466 \\
\hline $\mathrm{C}_{2} \mathrm{O}_{4}{ }^{2-}$ & ND & ND & ND & ND & ND & ND & ND & ND \\
\hline $\mathrm{Na}^{+}$ & ND & ND & 14.8 & 116 & ND & ND & 14.8 & 116 \\
\hline $\mathrm{NH}_{4}^{+}$ & 48.1 & 32.0 & 29.6 & 233 & 40.0 & 32.0 & 29.6 & 233 \\
\hline $\mathrm{K}^{+}$ & ND & 10.6 & 14.8 & 116 & 7.9 & 10.6 & 14.8 & 116 \\
\hline $\mathrm{Mg}^{2+}$ & ND & ND & ND & ND & ND & ND & ND & ND \\
\hline $\mathrm{Ca}^{2+}$ & 7.9 & 10.6 & 14.8 & 58.2 & 7.9 & 10.6 & 14.8 & 58.2 \\
\hline
\end{tabular}

a. Not detectable. $40 \mathrm{~km} / \mathrm{h}$ : constant speed of $40 \mathrm{~km} / \mathrm{h}, \mathrm{M}-15$ : M-15 test pattern, 60\%/40\%: 60\%-revolution/40\%-load.

conditions were the 11 elements: $\mathrm{Na}, \mathrm{Si}, \mathrm{S}, \mathrm{Cl}, \mathrm{Ca}, \mathrm{Mn}, \mathrm{Fe}, \mathrm{Ni}$, $\mathrm{Cu}, \mathrm{Zn}$ and $\mathrm{Pb}$, in $\mathrm{PM}_{2.5}$ and these plus $\mathrm{Mg}$ and $\mathrm{Ti}$ in $\mathrm{PM}_{10}$. The major element components of both $\mathrm{PM}_{2.5}$ and $\mathrm{PM}_{10}$ were $\mathrm{Na}$, $\mathrm{Mg}, \mathrm{Si}, \mathrm{S}, \mathrm{Cl}, \mathrm{Ca}, \mathrm{Fe}$ and $\mathrm{Zn}$. Elemental concentrations by sampling condition in both $\mathrm{PM}_{2.5}$ and $\mathrm{PM}_{10}$ in the order of lowest to highest were idling, constant speed of $40 \mathrm{~km} / \mathrm{h}$ and/or M-15 test pattern and 60\%-revolution/40\%-load. However, concentrations of sulfur were higher for idling than for constant speed of $40 \mathrm{~km} / \mathrm{h}$ or for M-15 test pattern in both $\mathrm{PM}_{2.5}$ and $\mathrm{PM}_{10}$. Concentrations under the sampling condition $60 \%$ revolution/40\%-load were several time to several dozen times higher than those under the other sampling conditions. In particular, under the sampling condition $60 \%$-revolution/40\%load, elements that increased dramatically were the major components: $\mathrm{Na}, \mathrm{Mg}, \mathrm{Si}, \mathrm{S}, \mathrm{Cl}, \mathrm{Ca}, \mathrm{Fe}$ and $\mathrm{Zn}$, in the cases of both $\mathrm{PM}_{2.5}$ and $\mathrm{PM}_{10}$. Furthermore, $\mathrm{Mg}$ and $\mathrm{Ti}$ were only detected under the sample condition $60 \%$-revolution/40\%-load for $\mathrm{PM}_{2.5}$. Comparing the element data for $\mathrm{PM}_{2.5}$ and $\mathrm{PM}_{10}$, as shown in Fig. 1, one finds that the elemental concentration ratio of $\mathrm{PM}_{2.5}$ and $\mathrm{PM}_{10}$ differed according to the sampling condition and one finds no definite tendency, but $\mathrm{PM}_{2.5}$ concentrations were $70 \%$ or more of $\mathrm{PM}_{10}$ concentrations for the majority of elements.

\section{Ionic composition}

As for ionic species, the anions $\mathrm{F}^{-}, \mathrm{Cl}^{-}, \mathrm{NO}_{2}^{-}, \mathrm{Br}^{-}, \mathrm{NO}_{3}^{-}$, $\mathrm{PO}_{4}{ }^{3-}, \mathrm{SO}_{4}{ }^{2-}$ and $\mathrm{C}_{2} \mathrm{O}_{4}{ }^{2-}$ and the cations $\mathrm{Na}^{+}, \mathrm{NH}_{4}{ }^{+}, \mathrm{K}^{+}, \mathrm{Mg}^{2+}$ and $\mathrm{Ca}^{2+}$ were analyzed. $\mathrm{Cl}^{-}, \mathrm{NO}_{3}{ }^{-}, \mathrm{SO}_{4}{ }^{2-}, \mathrm{Na}^{+}, \mathrm{NH}_{4}^{+}, \mathrm{K}^{+}$and $\mathrm{Ca}^{2+}$ were determined, of which $\mathrm{NO}_{2}^{-}, \mathrm{NO}_{3}^{-}, \mathrm{SO}_{4}^{2-}$ and $\mathrm{NH}_{4}^{-+}$were found to be the main components of both $\mathrm{PM}_{10}$ and $\mathrm{PM}_{2.5}$. The determination limit is $0.01 \mathrm{mg} / \mathrm{l}\left(0.03-0.3 \mu \mathrm{g} / \mathrm{m}^{3}\right)$ for all the ionic species, and concentrations of $\mathrm{F}^{-}, \mathrm{Br}^{-}, \mathrm{PO}_{4}^{3-}, \mathrm{C}_{2} \mathrm{O}_{4}{ }^{2-}$ and $\mathrm{Mg}^{2+}$ were smaller than $0.3 \mu \mathrm{g} / \mathrm{m}^{3}$ for all the samples.

Table 3 shows the ionic species concentrations of $\mathrm{PM}_{2.5}$ and $\mathrm{PM}_{10}$ in DEP under the sampling conditions. The ionic species concentrations shown in Table 3 are the actual values from exhaust calculated based on the dilution ratio, i.e., the emission volumes. Like the elements, the ionic species concentrations in both $\mathrm{PM}_{2.5}$ and $\mathrm{PM}_{10}$ in the order of lowest to highest were idling, constant speed of $40 \mathrm{~km} / \mathrm{h}$ and/or M-15 test pattern and $60 \%$-revolution/40\%-load. However, concentrations of $\mathrm{SO}_{4}{ }^{2-}$ and $\mathrm{NH}_{4}{ }^{+}$were higher for idling than for constant speed of 40 $\mathrm{km} / \mathrm{h}$ or for M-15 test pattern in both $\mathrm{PM}_{2.5}$ and $\mathrm{PM}_{10}$ Concentrations under the sampling condition $60 \%$ - 
revolution/40\%-load were several time to several dozen times higher than those under the other sampling conditions. Furthermore, $\mathrm{Cl}^{-}$was only detected under the sample condition $60 \%$-revolution/40\%-load. Comparing the ionic species data for $\mathrm{PM}_{2.5}$ and $\mathrm{PM}_{10}$, one finds that the concentrations of ionic species in $\mathrm{PM}_{2.5}$ and $\mathrm{PM}_{10}$ were almost identical.

\section{Conclusions}

The major elements of DEP were $\mathrm{Na}, \mathrm{Mg}, \mathrm{Si}, \mathrm{S}, \mathrm{Cl}, \mathrm{Ca}, \mathrm{Fe}$ and $\mathrm{Zn}$, and the main ionic species were $\mathrm{Cl}^{-}, \mathrm{NO}_{2}{ }^{-}, \mathrm{NO}_{3}{ }^{-}, \mathrm{SO}_{4}{ }^{2-}$, $\mathrm{Na}^{+}, \mathrm{K}^{+}$and $\mathrm{Ca}^{2+}$. The concentrations of these rose markedly when the load on the diesel engine was high. Comparing the element and ionic species data for $\mathrm{PM}_{2.5}$ and $\mathrm{PM}_{10}$, one finds that $\mathrm{PM}_{2.5}$ concentrations were $70 \%$ or more of $\mathrm{PM}_{10}$ concentrations for the majority of elements, and that concentrations of ionic species in $\mathrm{PM}_{2.5}$ and $\mathrm{PM}_{10}$ were almost identical.

\section{References}

1. Environment Agency Government of Japan, "Quality of The Environment in Japan 1997', 2000, Environment Agency, Tokyo, 120 - 128.

2. K. Yoshizumi, T. Watanabe, K. Ishii, H. Yoshida, K. Asakuno, T. Tamura, M. Kan, and N. Yoshino, "The source apportionment evaluation of ambient particulate matter in the Tokyo metropolitan area by a receptor oriented model",
1989, Annual Report of the Tokyo Metropolitan Research Institute for Environmental Protection 1989, Tokyo, 3 - 10.

3. K. Sakamoto, in Proceedings of the International Symposium on Ambient Fine Particles and Health, ed. Japan Society for Atmospheric Environment, 1999, Tokyo, Japan, $70-80$.

4. A. Mizohata, N. Ito, and Y. Kusuya, J. Jpn. Soc. Atmos. Environ., 2000, 35, 77.

5. R. D. McClellan, Ann. Rev. Pharmacol. Toxicol., 1989, 27, 279.

6. T. Ichinose, A. Furuyama, and M. Sagai, Toxicol., 1995, 99, 153.

7. H. Takano, T. Yoshikawa, Y. Miyabara, K. Imaoka, T. Ichiose, and M. Sagai, Am. J. Respir. Crit. Care Med., 1997, 156, 36.

8. K. Iwai and I. Utiyama, J. Jpn. Soc. Atmos. Environ., 2000, $35,229$.

9. JACP Diesel Vehicle Working Group, "Study of Current Diesel Vehicle and Fuel Influence on Emissions", JACP Technical Report 1-3-1, 2000, Petroleum Energy Center.

10. S. Hayakari and R. Hanaisi, J. Jpn. Soc. Atmos. Environ., 2001, 36, 39.

11. K. Sera, T. Yanagisawa, H. Tsunoda, S. Hutatukawa, Y. Saitoh, S. Suzuki, and H. Orihara, Intern. J. PIXE, 1992, 2, 325 .

12. K. Sera, S. Futatsugawa, and K. Saitoh, Intern. J. PIXE, 1997, 7, 71 .

13. K. Saitoh, K. Sera, T. Gotoh, and M. Nakamura, Nuclear Instrum. Methods Phys. B, 2002, 189, 86. 